\title{
Analisis Pengambilan Keputusan Perubahan Konversi Tambak Ikan ke Kebun Kelapa Sawit di Desa Kasano Kabupaten Mamuju Utara
}

\section{Analysis of Decision Making A Change of Conversion Fish Pond to Palm Oil Plantation in Kasano Village North Mamuju District}

\author{
Akbar Nasir ${ }^{*}$ Maryono $^{2}$ \\ ${ }^{1}$ Yayasan Pesantren Wahdah Islamiyah Pasangkayu \\ ${ }^{2}$ Politeknik Negeri Sambas
}

\section{Info Artikel:}

Diterima: $14 / 06 / 2021$

Disetujui: 09/07/2021

Dipublikasi: 01/10/2021

\section{Kata Kunci: \\ Konversi lahan, tambak ikan, kelapa sawit, nilai jual}

\section{Keywords:}

Land conversion, fish pond, palm oil, market value

*Korespondensi:

akbarnasir@gmail.com

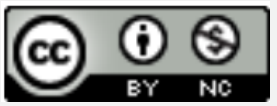

Copyright (C) 2021 Author(s)

\begin{abstract}
Abstrak. Penelitian ini bertujuan untuk mengetahui penyebab dan dampak terjadinya konversi tambak ikan menjadi kebun kelapa sawit di Desa Kasano, Mamuju Utara. Penelitian ini menggunakan metode kualitatif dengan pendekatan penelitian deskriptif. Pengumpulan data menggunakan teknik observasi dan wawancara langsung dengan nelayan yang merubah lahan tambaknya menjadi kebun kelapa sawit di Desa Kasano Kecamatan Baras Kabupaten Mamuju Utara. Hasil penelitian tersebut menunjukkan bahwa jumlah nelayan yang mengonversi tambaknya menjadi kebun kelapa sawit adalah sekitar $80 \%$. Konversi lahan terjadi secara berangsur-angsur, tidak ada perubahan status sosial akibat konversi lahan. Melainkan, pengonversian tambak tersebut karena permasalahan nilai jual kelapa sawit lebih besar dibandingkan ikan bandeng atau udang.
\end{abstract}

\begin{abstract}
This study aims to determine the causes and impacts of the conversion of fish ponds into oil palm plantations in Kasano Village, North Mamuju. This study uses a qualitative method with a descriptive research approach. Data collection used observation techniques and direct interviews with fishermen who converted their ponds into oil palm plantations in Kasanao Village, Baras District, North Mamuju Regency. The results of this study indicate that the number of fishermen who convert their ponds to oil palm plantations is around $80 \%$. Land conversion occurs gradually, there is no change in social status due to land conversion. Instead, the conversion of the ponds is due to the problem of the value of oil palm being higher than milkfish or shrimp.
\end{abstract}

\section{PENDAHULUAN}

Pada Tahun 2013, potensi lahan tambak di Kabupaten Mamuju Utara adalah 13.669.65 ha dengan 1.833,28 ha yang telah terkelola. Dari jumlah keseluruhan, Kecamatan Baras menyumbang potensi lahan tambak yang cukup besar, yaitu 2.056,36 hektar dengan 434,21 hektar lahan yang telah terkelola. Dari jumlah tersebut, Desa Kasano memiliki jumlah lahan terbesar yang telah terkelola, yaitu 362,1 hektar (BPS, 2014). Komoditi yang dibudidayakan pada tambak lebih dominan pada komoditi ikan bandeng dan udang windu.

Di samping itu, Mamuju Utara memiliki beberapa potensi perkebunan, salah satunya adalah kelapa sawit. Berdasarkan data yang 
dilansir oleh Badan Koordinasi Penanaman Modal, sejak tahun 2011-2013, produksi Kelapa sawit di Mamuju Utara terus mengalami peningkatan. Bahkan, pada tahun 2013 mencapai 807.570 ton dari 76.898 ton di tahun 2012. Selain itu, dari 304.375 hektar luas daerah Mamuju Utara, 37\% telah dialokasikan sebagai Hak Guna Usaha (HGU). Dari luasan tersebut, 90\% HGU digunakan untuk perkebunan sawit (Chandra, 2014).

Potensi tersebut memberikan kontribusi terhadap produsen minyak sawit mentah atau crude palm oil (CPO) di Indonesia sebesar CPO 24 juta ton per tahun, dengan komposisi 5 juta ton atau $5.5 \%$ per tahun dikonsumsi di dalam negeri. Salah satunya pengembangan produk kelapa sawit dari industri oleokimia dasar merangsang pertumbuhan industri barang konsumen seperti deterjen, sabun dan kosmetika (Suryana, 2007). Sementara 80\% sisanya diekspor (Hasan, 2013) dengan perolehan pendapatan sekitar USD 20 miliar (sekitar 10\% dari pendapatan ekspor total), terbesar kedua setelah minyak dan gas (pro-growth) (Hasan, 2013).

Di tengah dinamika ekonomi global yang terus berubah, sebagian besar petani tambak yang berada di Desa Kasano, Kecamatan Baras, Mamuju Utara mulai terpengaruh untuk beralih profesi menjadi petani kebun kelapa sawit. Potensi keuntungan dari satu kapling lahan sawit atau setara dua hektar yang menghasilkan pendapatan hingga empat juta rupiah per hektar, bahkan pemerintah daerah setempat mengklaim penghasilan sawit bisa mencapai sembilan juta rupiah per hektar (Chandra, 2014). Potensi tersebut dapat saling mempengaruhi antara penghasilan penduduk dengan pola pekerjaan begitupun sebaliknya. Konsekuensi lain adalah perubahan hubungan sosial oleh pola hidup serta perubahan pola interaksi yang biasa menjadi lebih luas sampai keluar daerah atau ke daerah perkotaan.

Faktor internal, eksternal ataupun gabungan kedua faktor tersebut yang bisa mempengaruhi perubahan mata pencaharian setiap orang (Waskimto, 2007). Perubahan usaha petani tambak ikan mengubah lahannya menjadi kebun kelapa sawit menjadikan hal tersebut menarik untuk dikaji. Pengonversian lahan tersebut terlepas dari tujuan untuk memaksimalkan keuntungan/ pendapatan lahan tersebut. Petambak harus rasional dalam memilih alternatif yang tersedia baginya untuk mengambil keputusan dalam kaitannya merubah tambak menjadi lahan kelapa sawit. Berdasarkan uraian tersebut, tujuan dari penelitian ini adalah untuk mengetahui penyebab dan dampak perubahan tambak ikan menjadi kebun kelapa sawit.

\section{METODE PENELITIAN}

Penelitian ini dilakukan pada Bulan Januari-Maret 2015, bertempat di Desa Kasano, Kecamatan Baras, Kabupaten Mamuju Utara. Lokasi ini 
dipilih secara sengaja (purposive) dengan pertimbangan bahwa di lokasi ini sebelumnya banyak lahan tambak (bandeng) dan saat ini telah dikonversi menjadi kebun kelapa sawit. Metode penelitian ini adalah metode kualitatif dengan penelitian deksriptif yang menggunakan beberapa pendekatan seperti (oralhistory) atau jejak sejarah dari satu objek dengan wawancara mendalam (in-depth interview). Sehingga penelitian ini bersifat korelasi atau berhubungan, maka ukuran sampel sekurang-kurangnya adalah sebesar 30 subjek (Gay \& Diehl, 1992). Jumlah populasi petani tambak yang mengonversi lahannya sebanyak 116 orang (BPS, 2014) yang dianggap semua homogen (sama) berdasarkan kepemilikan tambak yang kemudian dikonversi ke kebun kelapa sawit. Penentuan jumlah sampel atau responden berdasarkan (Gay dan Diehl, 1992) maka jumlah responden sebanyak 30 orang. Adapun teknik pengumpulan data dengan 3 metode, yaitu: observasi, wawancara mendalam (in-depth interview) dan studi literatur.

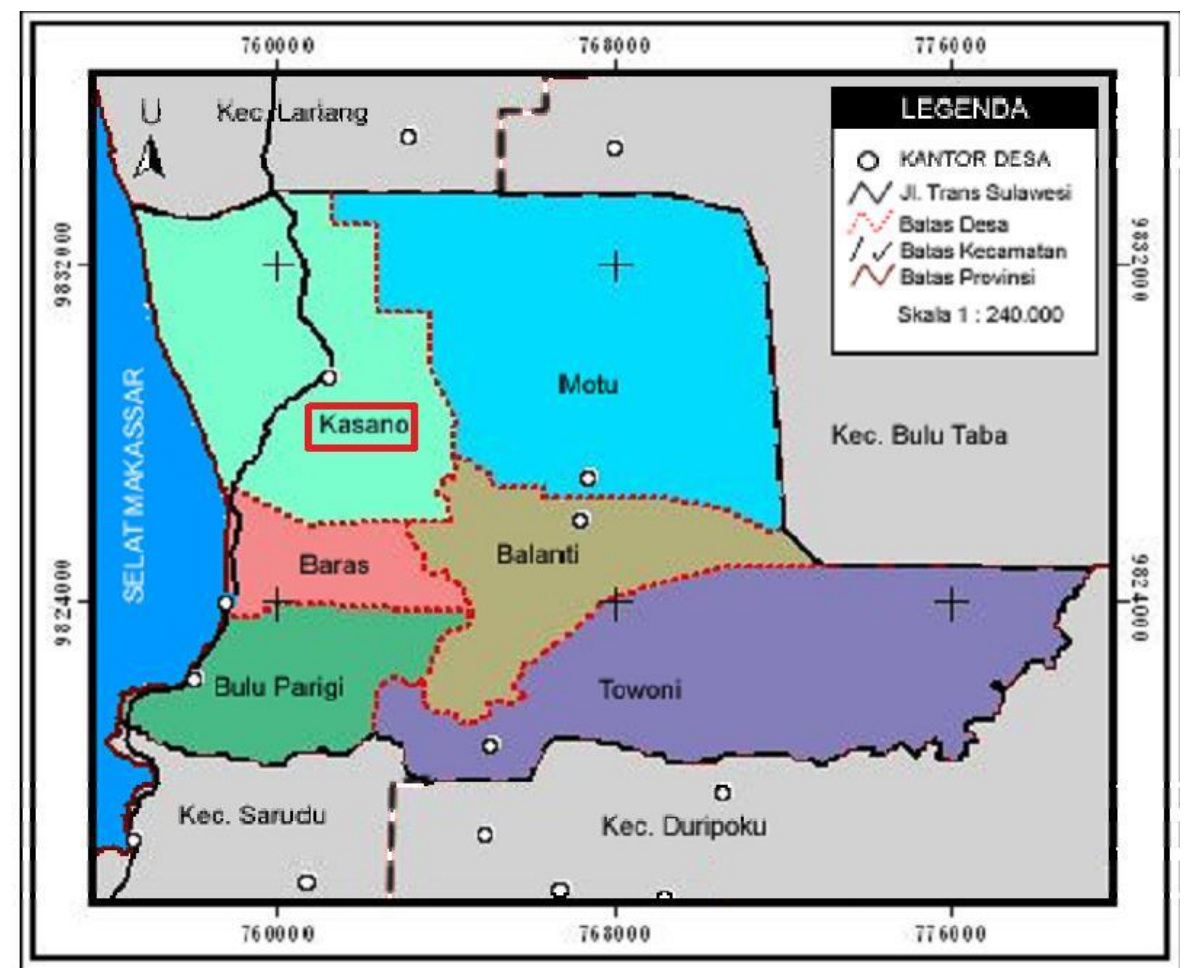

Gambar 1. Lokasi Penelitian

Data yang diperoleh baik data primer maupun data sekunder dianalisis secara deskriptif sehingga menggambarkan hubungan-hubungan dari beberapa variabel yang diambil untuk menjawab tujuan penelitian. Sedangkan analisis data yang digunakan ialah analisis deskriptif korelasi yaitu menjelaskan hasil yang diperoleh dengan bantuan grafik. Berdasarkan grafik tersebut akan dijelaskan berbagai variabel yang terkait dengan sejarah dan dampak perubahan fungsi lahan tambak menjadi lahan kebun Kelapa sawit. 


\section{HASIL DAN PEMBAHASAN}

\section{Status sosial masyarakat Desa Kasano}

Pada umumnya masyarakat di Desa Kasano terdiri dari beberapa suku dari berbagai daerah yaitu, suku Kaili, suku Mandar, suku Bugis, suku Jawa, dan suku Bali. Suku yang paling tua dan paling dominan yaitu suku Kaili dan Bugis. Pola stratifikasi yang membedakan setiap lapisan masyarakat ialah kasta pendidikan, pendapatan atau ekonomi. Pola tersebut dapat dilihat pada status sosial masyarakat Desa Kasano baik secara vertikal maupun secara horizontal dipandang dari jabatan, harta serta pendidikan. Kendala terkait mobilitas sosial di Desa Kasano yaitu masih banyak daerah terpencil untuk diakses. Padahal pergerakan secara vertikal maupun horizontal cukup terbuka secara luas.

Masyarakat Desa Kasano yang mengonversi lahan mereka dari petani tambak ke petani kelapa sawit tidak merasakan perbedaan dalam status sosial mereka dengan kata lain status sosial secara horizontal karena status pekerjaan sebelumnya tetap sama menjadi seorang petani (mobilitas horizontal) walaupun dengan pendapatan yang berbeda. Beda halnya jika masyarakat Desa Kasano yang dulunya memiliki tambak dan mengubahnya ke kebun kelapa sawit dan merubah kesejahteraan mereka maka perubahan status sosial mereka secara vertikal yang dulunya miskin sekarang serba berkecukupan (mobilitas vertikal). Hal ini senada dengan Tahyudin (2000) bahwa setiap orang memiliki peluang yang sama dalam meningkatkan strata di berbagai bidang seperti ekonomi, politik dan ilmu pengetahuan. Hal inilah yang kita sebut sebagai pola stratifikasi sosial masyarakat bersifat terbuka, misalnya dibidang pendidikan tidak menutup kemungkinan orang biasa atau miskin bisa mengenyam pendidikan tinggi dengan beasiswa.

\section{Terjadinya konversi lahan}

Konversi lahan tambak menjadi kebun kelapa sawit di Desa Kasano terjadi sejak Tahun 1999. Konversi lahan ini tidak terjadi secara serentak, akan tetapi terjadi secara berangsur-angsur. Pada tahun 2000 hingga 2008, para petani satu persatu mengonversi lahan tambaknya menjadi lahan perkebunan kelapa sawit. Disebabkan karena pada proses budidaya tambak pada waktu itu sering terjadi masalah. Masalah-masalah tersebut ialah berupa penyakit pada ikan bandeng, banyaknya hama pada tambak seperti predator. Selain itu, perubahan cuaca dan suhu lingkungan yang selalu berubah dan tidak seperti biasanya. Intensitas curah hujan yang tinggi menyebabkan lahan tambak banjir sehingga air tambak berubah menjadi air tawar. Hal ini juga berpengaruh pada tambak sehingga menyebabkan kematian pada peliharaan.

Di waktu yang bersamaan, bermunculan isu pengelolaan perkebunan kelapa sawit yang lebih menjanjikan. Terlebih lagi, ada dukungan dari 
pemerintah setempat agar masyarakatnya mulai melakukan pekerjaan perkebunan kelapa sawit. Salah satunya terkait pengembangan jaringan jalan khusus berupa jaringan jalan yang berada di dalam perkebunan kelapa sawit. Faktor ini menjadi salah satu faktor pendukung para masyarakat mengonversi lahan tambak mereka, padahal sektor pangan juga menjadi prioritas yang tidak boleh dilupakan (Maman, 2013). Dukungan tersebut berupa pemberian bibit kelapa sawit gratis kepada petani yang akan mengembangkan lahannya menjadi perkebunan kelapa sawit.

Para petani di Desa Kasano pun melihat proses penghasilan yang lebih baik dengan melakukan perkebunan kelapa sawit. Penghasilan lebih baik yang dimaksud ialah, rentan waktu penghasilan yang satu kepenghasilan berikutnya lebih cepat ketimbang satu periode panen untuk tambak. Jika saat mengelolah tambak para petani mesti menunggu hingga 4-6 bulan untuk sekali panen atau untuk mendapat penghasilan. Di perkebunan kelapa sawit hanya membutuhkan waktu dua minggu hingga satu bulan untuk mendapatkan penghasilan.

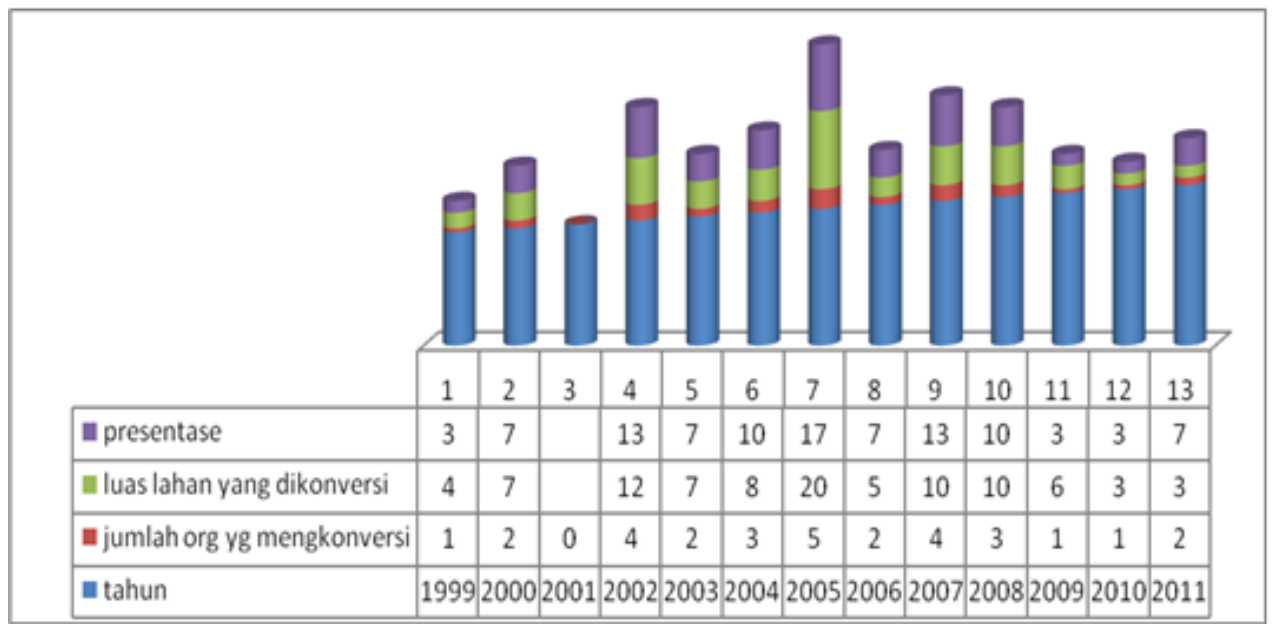

Gambar 2. Konversi lahan per tahun

Dari grafik di atas dapat diketahui bahwa lahan tambak berkurang sejak tahun 2000 dan mencapai puncak pada tahun 2005 ke atas, sedangkan pada tahun yang sama lahan kelapa sawit mengalami peningkatan kurang lebih 87 hektar. Besaran konversi lahan yang terjadi tidak sama disetiap orangnya karena mereka masing-masing memiliki luas lahan yang berbeda-beda. Perubahan lahan yang sebagian besar dalam satuan hektar tersebut menjadi bukti bahwa sebagian besar mengonversi lahan mereka ke kebun kelapa sawit.

\section{Penyebab konversi lahan}

Perubahan mata pencaharian dalam hal ini konversi lahan yang dilakukan masyarakat Desa Kasano tersebut bukan tidak memiliki alasan. Menurut Kurdianto (2011) perubahan alih fungsi atau konversi lahan 
tersebut disebabkan berbagai hal yaitu pendapatan usahatani kelapa sawit lebih tinggi dengan resiko lebih rendah, nilai jual/agunan kebun lebih tinggi, biaya produksi lebih rendah serta penggunaan air yang lebih sedikit. Hal yang sama dikemukakan oleh (Astuti et al., 2011) bahwa faktor utama perubahan alih fungsi lahan pangan menjadi kebun kelapa sawit adalah pertimbangan aspek ekonomi. Selain itu, aspek teknis juga menjadi alasan konversi lahan tersebut misalnya kelapa sawit yang tidak mudah terkena penyakit dibanding tambak, jadwal panen yang lebih sering dari pada tambak, pasar kelapa sawit pun lebih cepat dan mudah (tersedia terus) dibanding tambak, bibit ikan dan udang lebih susah dibanding bibit kelapa sawit. Aspek teknis seperti tanaman sawit lebih berumur panjang, proses pascapanen lebih mudah, teknik budidaya lebih mudah dan pengadaan pupuk lebih mudah (Astuti et al., 2011). Permasalahan teknis sangat mengganggu proses pemeliharaan tambak, sehingga tak heran jika permasalahan tersebut menyebabkan kerugian pada petambak. Secara prosedural tahapan usaha tambak tidak mengalami kendala selama proses praproduksi, produksi sampai panen. Tahap pascapanen yang menjadi kendala utama karena petambak mesti menunggu pengumpul datang agar bisa memanen hasil tambaknya. Dan jumlah yang akan dibeli pun ditentukan oleh petambak. Sehingga, terkadang petambak tidak dapat memanen hasil tambaknya sekaligus karena tergantung kapan pengumpul datang untuk mengambil hasil tambak. Maka keresahan petambak akan hal tersebut menjadi salah satu pertimbangan kuat untuk beralih profesi. Alasan kuat yang lainnya untuk beralih profesi dari petambak menjadi petani kelapa sawit ialah dari segi pemasarannya. Jika para petani melakukan usaha perkebunan kelapa sawit, mereka tak perlu khawatir lagi masalah penjualan hasil panennya. Sebab perusahaan pengolah kelapa sawit setempat selalu bersedia membeli hasil panen petani kapanpun mereka melakukan panen.

Setiap periode pemeliharaan para petani mesti mencari bibit baru agar usaha tambaknya tetap berjalan. Sedangkan untuk usaha perkebunan kelapa sawit, para petani tak perlu mencari bibit setiap periode untuk panen. Karena bibit kelapa sawit sekali ditanam akan digunakan selamanya, selama melakukan usaha tersebut. Petani hanya cukup untuk memetik (panen) hasilnya setiap periode. Hanya saja, waktu yang dibutuhkan dari proses penanaman bibit hingga awal panen, usaha perkebunan kelapa sawit terbilang lama. Waktu yang dibutuhkan dari penanaman bibit hingga panen pertama kurang lebih lima tahun. Walaupun waktu untuk panen cukup lama, hal ini tidak menjadi masalah untuk para petani kelapa sawit karena rata-rata pemilik lahan tersebut menjadikan profesi petani kelapa sawit sebagai pekerjaan sampingan. Namun setelah itu petani akan dimanjakan dengan hasil panen yang berkesinambungan tanpa menyediakan bibit. 
Berdasarkan pemaparan dan beberapa kutipan di atas, maka dapat disimpulkan beberapa alasan yang menjadi penyebab masyarakat Desa Kasano mengonversi lahannya dari lahan tambak menjadi kebun kelapa sawit. Alasan tersebut terbagi dua segi, yaitu dari segi teknis dan segi pasar.

Berdasarkan aspek teknis yaitu:

a. Risiko usaha tambak lebih tinggi, disebabkan wabah penyakit, iklim, kualitas air, sumber air, dan predator.

b. Susahnya untuk menemukan bibit.

c. Periode panen tambak lebih cepat 3-5 bulan, namun stagnan dengan rentang waktu tersebut. Sedangkan panen kebun kelapa sawit harus menunggu 5 tahun untuk panen awal, setelahnya dapat panen 2-3 kali dalam sebulan.

Berdasarkan aspek pemasaran yaitu:

a. Pemanenan tidak serta-merta dapat dilakukan, meskipun ikan budidaya sudah siap panen. Pemanenan dilakukan hanya ketika ada pembeli yang datang, baik konsumen untuk konsumsi rumah tangga maupun pengumpul yang membeliuntuk dijual kembali ke masyarakat.

b. Sedangkan usaha kelapa sawit sudah ada perusahaan yang siap membeli hasil panen buah kelapa sawit.

\section{Dampak konversi lahan}

Dampak pada perubahan status sosial tidak berubah hanya mata pencaharian saja yang berganti. Sebab tidak ada perbedaan profesi antara pekerjaan sebelumnya dengan pekerjaan sekarang. Sebelumnya, masyarakat berprofesi sebagai petani tambak, sekarang masyarakat berprofesi sebagai petani kelapa sawit, sama-sama sebagai seorang petani. Pada struktur sosial, hal ini termasuk dalam mobilitas horizontal. Hal ini juga sesuai dengan teori mobilitas sosial, bahwa mobilitas status sosial para petambak mengalami perubahan mobilitas horisontal. Dengan kata lain status sosialnya berpindah mendatar. Tidak ada peningkatan maupun penurunan pekerjaan atau status sosial.

Petani tambak ikan bandeng menjual dengan kisaran harga Rp 7.000 - Rp 13.000/kg tergantung seberapa banyak permintaan konsumen yang tidak menentu. Sedangkan harga sawit Rp 800/kg, setiap 1 pohon memiliki 1-5 tandan, dan setiap 1 tandan beratnya $15-80 \mathrm{~kg}$. Walaupun masa panen sawit lebih lama setelah 5 tahun baru bisa panen 2-3 kali setiap bulannya, sedangkan tambak dipanen 4-6 bulan. Berdasarkan hasil wawancara ratarata hasil panen sawit yang didapatkan rata-rata $450 \mathrm{~kg} /$ panen dengan pendapatan berkisar rata-rata $\mathrm{Rp} 1.500 .000 /$ ha bisa lebih besar dan lebih kecil tergantung jumlah pohon dalam 1 ha. Berdasarkan hal itu, pendapatan dari usaha kebun kelapa sawit lebih tinggi dibandingkan dengan petani tambak. 


\section{KESIMPULAN}

Penyebabnya karena permasalahan pasar sawit lebih baik dibandingkan hasil tambak ikan atau udang dan permasalahan teknis seperti perubahan iklim, predator (hama), ketersediaan bibit ikan atau udang yang susah, dan diperlukan pengawasan secara ketat. Sedangkan pada status sosial tidak mengalami perubahan tetapi pada struktur sosial mengalami mobilitas horizontal.

\section{DAFTAR PUSTAKA}

Astuti, U. P., Wibawa, W., \& Ishak, A. (2011). Lahan Pangan Menjadi Kelapa Sawit Di Bengkulu: Kasus Petani di Desa Kungkai Baru. Prosiding Seminar Nasional, 189-195.

Badan Pusat Statistik. (2014). Mamuju Utara dalam Angka Tahun 2014. BPS Mamuju Utara. Sulawesi Selatan.

Chandra, W. (2014). Kala Sawah dan Gunung Mamuju Utara jadi Kebun Sawit. Diakses pada tanggal 04 Agustus 2015. http://www.mongabay.co.id/2014/12/12/kala-sawah-dan-gunungMamujuutara-jadi-kebun-sawit/

Gay, L. R., \& Diehl, P. L. (1992). Research methods for business and management. Macmillan Pub. Co.; Maxwell Macmillan Canada; Maxwell Macmillan International.

Hasan, M.F. (2013). Sawit, Salah Satu Sumber Paling Kompetitif Di Dunia Untuk Biofuels. http://tabloiddiplomasi.org

Kurdianto, D. (2011). Alih Fungsi Lahan Pertanian ke Tanaman Kelapa Sawit. http:// uripsantoso.wordpress.com

Maman, U. (2013). Konversi Lahan Pertanian dan Persoalan Kedaulatan Pangan. Jurnal Agribisnis, 7(1), 77-90. https://doi.org/10.15408/aj.v7i1.5171

Tahyudin, D. (2000). Needs Assesment Dalam Rangka Pemberdayaan Masyarakat di Sekitar Lokasi Penambangan Timah di Pulau Bangka Belitung. Lembaga Penelitian Universitas Sriwijaya, Palembang.

Waskito, W.S. (2007). Pergeseran Mata Pencaharian Masyarakat Desa. Universitas Sebelas Maret. 